\title{
Air Quality Degradation: Can Economics Help in Measuring its Welfare Effects? A Review of Economic Valuation Studies
}

\author{
Eva Kougea and Phoebe Koundouri \\ Athens University of Economics and Business (AUEB)
}

Greece

\section{Introduction}

Air quality affects human's well being in various ways. Air providing the most important life-support function sustains human health and enables the existence of all ecosystems. Although clean air is considered to be a basic requirement for human health and well-being, economic development and population growth has resulted in a considerable deterioration of air quality. Human activities like the intensification of agriculture, industrialization, increasing energy use, the burning of fossil fuels and the increase in transportation have resulted to a rising cocktail of poisonous pollutants which impose many adverse effects on environment as a whole, our human health and life expectancy, ecosystems services, biodiversity, agricultural crops and building structures.

Under an economic perception excessive air pollution is partly caused by the existence of externalities mainly associated with missing markets or missing property rights. Social cost of air pollution is not covered by the polluting activities nor is reflected on market prices but it is imposed on everybody. The first part of this chapter refers to the theoretical framework of welfare economics and provides a brief description of fundamental issues arising in such environmental problems.

Economists have developed various approaches in order to be able to quantify values associated with non marketed environmental goods, in this case air quality. The next part of this chapter describes the currently available methods and techniques for estimating monetary values of changes in well-being due to air pollution. The methods will be presented can be classified into two broad categories, namely revealed preference techniques (cost of illness, human capital surveys, hedonic pricing, Quality Adjusted Life Years) and stated preference techniques (contingent valuation method and choice experiment).

The rest of the chapter provides a review of the existing literature on economic valuation studies which have attempted to elicit monetary values associated with air pollution, focusing in particular on human health, ecosystems services and buildings. Our aim is to provide a critical overview of the estimated benefits that public derive from an increase in air quality (or a reduction in environmental risk) by presenting a synthesis of the available quantitative empirical results. Finally, it follows a discussion regarding the usefulness of valuation studies in a policy context. 


\section{Theoretical concepts}

The aim of this section is to provide a short introduction on the underlying economic theory with respect to non-marketed environmental goods such as air quality. Also explains the nature and the components of values individuals may derive from air quality improvement.

\subsection{Air pollution as a public bad}

Air quality under an economic perspective is a pure public good as it is characterized by both non-rivalry and non excludability in consumption. Respectively, air pollution can be seen as a public bad. Everyone breaths the air, it is not feasible for individuals to prevent themselves from exposure to ambient air pollution. In other words individuals are not free to vary independently the levels of the services of the environmental good they consumed, in this case air. This public good feature leads to market failure mainly associated with missing property rights and presence of externalities.

Air pollution is the most common form of an environmental externality. An externality arises when social or economic activities of one group of persons have an impact on another and when that impact is not fully informed or compensated for by the first group (Externe, 2005). Most economic activities emit a mixture of pollutants. These pollutants may create a health risk or disturb ecosystems. Though these damages are a cost to society, the polluter has no incentive to account for these damages when making decisions. Not only production of goods can generate external effects. In many cases consumption of goods can influence the size of externalities considerably (i.e. choice of mean of transport or fuel type). In both cases environmental costs of goods are ignored resulting to a lower private cost and thereby excessive production or consumption of the good that generates the externality.

Generally, from a microeconomic view, prices due to the presence of externalities are not the correct signals therefore market fails to obtain optimal social outcome. This means that private optimum divergences from social optimal allocation of the resources as the cost of air pollution is not covered by the polluting activities nor is reflected on market prices but it is imposed on everybody. Economic instruments should be employed in order to internalize externalities into the decision process. In order to do so first it is required to measure the damages to society in monetary terms and explore how external costs can be charged to consumers and producers.

\subsection{Total economic value}

The concept of total economic value is an essential theoretical framework for the implementation of economic valuation exercises. Individuals' preferences play the most important role on determining the value of an environmental good. Air provides a diverse array of goods and services which can be translated to values that directly or indirectly human society undertakes. Preferences actually reflect utilities individuals expect to derive from the consumption of a resource, given the needs the wants and the wishes. Total Economic Value (TEV) of a resource is the whole class of values that have a basis in human preferences (Karousakis \& Koundouri, 2006).

Individuals are expected to derive utility from the consumption of a good or service. This is called actual use value and is composed of direct use value (i.e. commercial and recreational) and indirect use value (i.e. amenity value). People may also derive utility from retaining an option to a good or service. Option value reflects the potential future direct and indirect use values. Non-use values reflect individual preferences that may exist for an environmental 
good even when no actual or future use is expected to be made. Examples of non-use values are the existence values derived from the demand to preserve the existence of resources unrelated to any use and the bequest and altruistic values. The latter involve individuals' willingness to pay for an environmental resource for others, i.e. children or future generations.

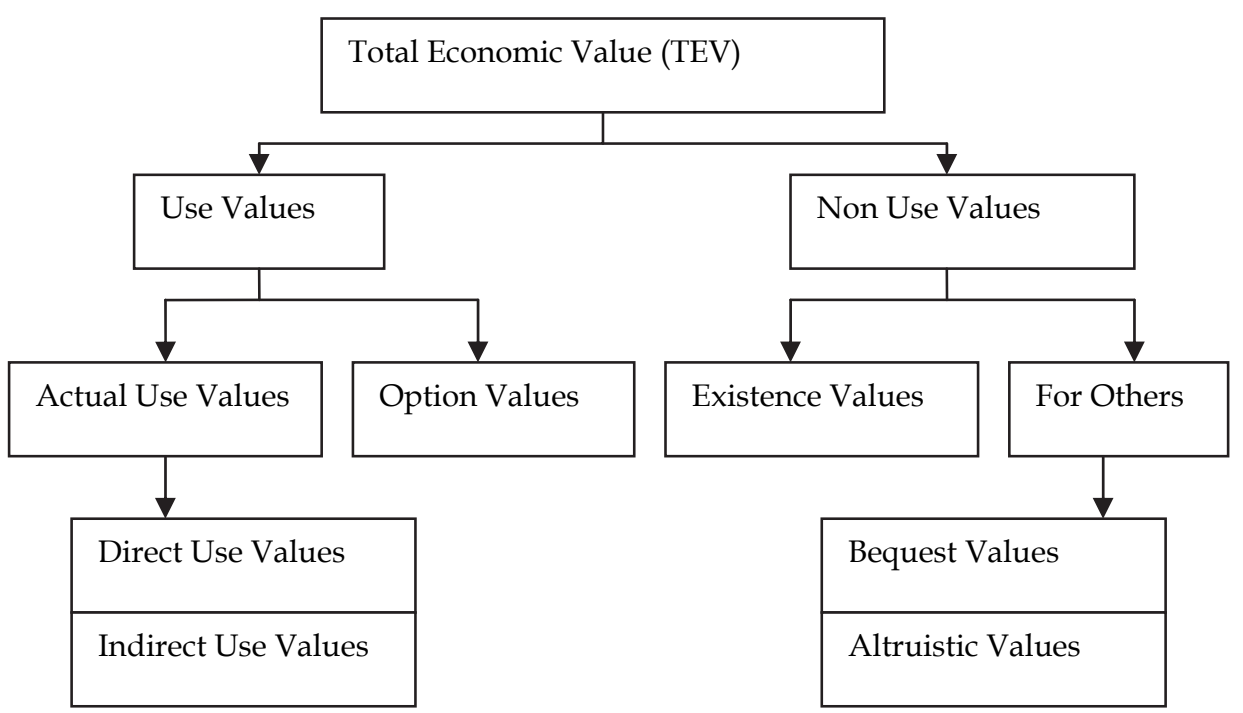

Fig. 1. Total Economic Value and its Components

Air pollution may influence all these elements of value. Economists in pollution control appraisal and in valuation exercises should consider all components of total economic value that are being influenced by the policy in question as TEV elements reflects the true value society undertakes from welfare changes due to an improvement or a deterioration of air quality.

\section{Economic valuation techniques}

The purpose of economic valuation is to capture the real economic values which contribute to the social welfare. Economic valuation refers to the assignment of money values, which have a particular and precise meaning, to non-marketed assets, goods and services (Pearce et al., 2002). A variety of techniques are available, the main methodological approaches of economic valuation can be broadly classified into revealed and stated preferences techniques.

Revealed Preferences (RP) techniques rely on market observations to capture the value of an environmental good that it is not itself traded in any market but is in a way connected with other marketed goods. From people's behavior in markets there is a possibility of isolating values of changes in environmental goods. Revealed preferences techniques include: Cost of Illness, Human Capital Surveys, Hedonic Pricing and the Quality Adjusted Life Year. 
Hedonic Price Method (HPM) can be used to estimate the demand for air quality improvements. The most common implementation of hedonic pricing is in the housing markets. The theoretical structure behind hedonic pricing assumes that households, when making housing choices, consider a vector of characteristics including among others environmental factors as air pollution. Air pollution and environmental degradation can have direct impact on property values. It is expected that properties in areas with severe pollution problems will experience lower prices compared with properties located in areas of high air quality. HPM involves the estimation of a hedonic housing value equation with air pollution or other environmental factor as one of the housing attributes. Econometrical analysis will reveal each household's willingness to pay for a marginal change in air pollution from the hedonic housing value equation. A marginal WTP function for all households in the urban area examined is analogous to a demand curve for clean air.

Averting costs is the sum of the defensive and preventive expenditures that an individual is willing to make in order to avoid or reduce the risk of a negative impact. Rational individuals will be willing to spend money on activities that reduce the risk of air pollution up to the point where the marginal averting cost equals marginal value of reduced impact. The advantage of that technique is that makes direct use of market observable prices. With the same logic, in terms of human health, Cost of illness (COI) can be measured by the sum of the direct costs (medical costs, nursing care etc.) and indirect opportunity costs (i.e. loss of working days) associated with a disease and estimate the potential savings from the avoidance of the disease. Human Capital Surveys are employed to estimate the productivity loss measured in workdays due to illness. Also one can value loss of life based on foregone earnings associated with premature mortality. Quality Adjusted Life Years (QALYs) is an alternative measure to value reductions in health risks. Based on individuals' preferences it captures both the qualitative and quantitative aspects of life. An individual health is measured in terms of QALYs score. These scores are invariant across individuals in the same health state and range from 0 (death) to 1 (perfectly health), (Wagstaff, 1991). A similar measure closely related to QALYs is the Disability Adjusted Life Years (DALYs). The main difference is that QALYs measure the value of a health profile relative to immediate health while DALYs incorporate a weighting factor that depends on age and measure the loss of longevity and health from an idealized health profile (Hammit, 2002).

Stated Preferences (SP) techniques are the most comprehensive and commonly used methods. In SP studies the market for the good is being constructed through the use of questionnaires. In this hypothetical market individuals have the opportunity to pay for an environmental improvement that will increase their utility or to accept compensation for an environmental deterioration that will decrease their utility. The most common forms of SP techniques are the Contingent Valuation Method and Choice Experiments.

Contingent Valuation (CV) is a survey based method technique in which a hypothetical market is being created and respondents are directly asked to express their willingness to pay contingent on some hypothetical change in the future state of environmental conditions (Mitchell \& Carson, 1989). Alternatively, in case of an environmental deterioration this can be expressed as the minimum monetary compensation they would accept to tolerate the reduction in environmental quality. Individual's WTP estimates are very sensitive on the description of the contingent market, thereby information respondents have about the environmental good is determining the quality of the estimates. Thus the description of the environmental change in question and the contingent market must be presented carefully 
with great detail. Of the same importance is the choice of a payment vehicle, i.e. increase in taxes vs. voluntary donations, as well as the form of the contingent valuation question i.e. an open-ended format vs. a double-bounded dichotomous choice mechanism. The literature on the contingent valuation method's advantages and disadvantages is large. There are many problems associated with CVM that may bias the value estimates (e.g. interviewing bias, non-response bias, strategic bias, embedding effects, yea-saying bias, hypothetical bias, information bias) (Bateman et al., 2002). NOOA Panel set the guidelines for the implementation of reliable contingent valuation exercises (Arrow et al., 1993). Recommendations among others refer to the choice formats i.e. dichotomous choice over other alternatives and to the choice of data collection, i.e. face to face interviews are preferable to web surveys.

Choice Experiment (CE) method is another survey based technique which can estimate the total economic value of an environmental good and its attributes as well as the value of more complex changes in several attributes. Each respondent is presented with a series of alternatives of an environmental stock, flow or service with varying levels of its price and attributes and asked to choose the most preferred option in each set of alternatives. A status quo alternative is included in each choice set. The selected attributes in each case are ought to be part of people's preference for the environmental change being considered and can be impacted by a management policy option (Bateman et al., 2002). The main advantage of this approach is the ability to measure the trade-off individuals make between different attributes and levels and that is possible to measure all elements of economic values like non-use values, i.e. existence and bequest. Another advantage of choice experiments is that eliminates or minimises several of the problems attached to contingent valuation like strategic bias, yea-saying bias, embedding effects (Bateman et al., 2002).

Due to the high cost and time demands needed to perform an original valuation study Benefit Transfers techniques have been developed. According to Rosenberg \& Loomis (2001) benefit transfer is defined as the adaptation and use of existing economic information derived for specific sites under certain resources and policy conditions to new contexts or sites with similar resources and conditions. Navrud (2004) defines a typology of the most usual benefit transfer methods, namely the unit value transfer approach, unit transfers with adjustment to reflect site specific features and the benefit function transfer.

Finally it must be mentioned that a major part of the literature on economic valuation relies on constructing dose-response function and damage functions. They both reveal a technical or a biological relationship between quantities of a pollutant that affects a receptor with the physical impact on this receptor (Mitchell \& Carson, 1989). These relationships can serve at the most as an aid in a monetary valuation study. Such dose-response functions are available for a range of pollutants and their physical impact on human health, building materials and agricultural crops.

Each technique described in this section has its own advantages and limitations. The selection of the appropriate technique should be case driven and be dependent of the policy examined. All available techniques differ in the data demands, assumptions and in the values that are able to capture. There are many methodological problems associated with the use of housing markets data or other revealed preference method to measure willingness to pay for clean air. The main limitation of these techniques is the capability to measure only a subset of the values people are willing to pay. They can capture only use values while they fail to isolate 'non-use' elements of value. Stated preference techniques have the advantage that can estimate non use values. Use values can be estimated by both revealed and stated preference techniques. 


\section{Economic assessment of air pollution: empirical evidence}

In the subsequent section important applications of the valuation techniques that have been conducted to estimate social benefits associated with increased air quality are reviewed. The review is by no means exhaustive but aims to highlight the benefits of using economic valuation techniques as tools that can facilitate the formulation of stronger management policies that account more fully for the total economic value generated by air quality improvements. For quick reference, at the end of the chapter will be provided a table summarizing each study's mains features i.e. author, case study country, valuation technique and valuation result.

\subsection{Air pollution human health and well-being}

There is an increasing recognition that air pollution is a major environmental risk to health. Current concentrations of air pollutants have been associated with adverse long and short term health effects including an increase in mortality (Katsouyanni, 2003). According to the European Commission's Clean Air for Europe poor air quality results in several hundreds of thousands premature deaths in Europe each year, increased hospital admissions, extra medication and millions of lost working days (CAFE, 2005). In line with this, a large number of valuation studies trying to quantify environmental impacts on human health in monetary terms and elicit preferences for health and environmental policies that reduce the risk of illness or even mortality have appeared in the literature worldwide.

Many authors have reviewed studies addressing issues of economic valuation of air pollution and human health. Bell et al. (2008) review the literature on valuation studies assessing health consequences from greenhouses gases. The review was restricted to health benefits from air pollution exposure. Pearce (1996) also provides a summary of the main studies conducted to that day valuing health damages from air pollution focusing in developing countries. Preliminary work indicates that some air pollutants, like particulate pollution and lead, are associated with high damage in monetary terms for the developing world. Another review of the economic literature on the effects of environmental changes on public health, in both developed and developing world is presented by Remoundou \& Koundouri (2009).

Contingent valuation studies dominate the literature addressing air pollution control assessment in both developed and developing world. In these studies health consequences of alternative air pollution mitigation strategies are presented in a valuation scenario and individuals are asked to state their maximum willingness to pay for the implementation of the policy under evaluation.

In Europe, mortality risk reductions issues expressed as extension in life expectancy are addressed by Desaigues et al. (2004) and Chilton et al. (2004). Desaigues et al. (2004) performed a contingent valuation study in France employing a questionnaire originally developed by Krupnick et al. (2002) in order to impute a value on air pollution mortality. Results from the survey used to provide estimates of value of statistical life and of value of life years. Each respondent expressed his/her willingness to pay annually during the next 10 years for a medical treatment that would reduce the risk of dying by 1 in 1000 and by 5 in 1000, estimated WTP is $412 €$ and $563 €$ respectively. Authors also review the valuation literature of a gain in life expectancy due to air pollution reductions. Another similar study is made by Chilton et al. (2004) who conduct a contingent valuation exercise in UK. In total 665 persons divided in 3 sub-samples were asked to value a bundle of health impacts of air pollution on months of extra life expectancy in normal health, months of extra life in poor health, avoiding hospital 
admissions, and avoiding breathing discomfort. Each sample was provided with different information regarding time horizon, i.e. one month, three months and six months avoidance of health symptoms. Respondents are asked about their annual WTP for the rest of their life. The mean annual WTP for chronic mortality is £ 29.52 for the one month sample, $£ 30.21$ for the three months sample and $£ 38.73$ for the six month sample. The value of one life year is $£ 27,630$, $£ 9,430$ and $£ 6,040$ for the one, three and six months sample respectively.

Focusing on human morbidity from air pollution, Navrud (2001) conduct a contingent valuation study to assess the benefits from morbidity risk reduction in Norway, Europe. This study aimed to elicit willingness-to-pay estimates to avoid additional days of seven lights health symptoms (coughing, sinus congestion, throat congestion, eye irritation, headache, shortness of breath and acute bronchitis) and asthma. The survey was conducted with face to face interviews of 1009 individuals. Mean WTP for an environmental program that would result to health risk reduction, i.e. avoidance of one additional day of health symptoms ranged from 99 NOK for coughing to 267 NOK for shortness of breath. WTP per person to avoid 14 additional days per year of light health symptoms ranged from 267 NOK for coughing to $812 \mathrm{NOK}$ for shortness of breath. Authors also compared values estimates from this study with estimate from other similar US studies. Results showed that respiratory symptom days and asthma attacks are valued lower in Norway than in the US.

Carlsson \& Johansson-Stenman (2000) implement a contingent valuation method to measure the benefits associated with increased air quality in Sweden. The mean WTP for a $50 \%$ reduction of harmful substances where the respondents live and work was about 2000 SEK/year (160SEK/month). WTP was found to increase in income, wealth and education. Also it was larger for men, members of environmental organizations, people living in big cities and people who own their house or apartment. Results seem to conform in general to the estimates of a previous stated preferences study of Halvoren (1996) in Norway. Results from a contingent valuation indicated that the WTP for a $50 \%$ reduction in air pollution due to reduced emissions from traffic is about 1250 SEK / year and person.

Dziegielewska \& Mendelsohn (2005) employed a contingent valuation study to estimate the willingness to pay of Polish people to harmonize national air pollution standards with EU standards. Analysis designed to estimate a value of a $50 \%$ reduction in air pollution that in general correspond to EU standards for PM10 and a value of $25 \%$ reduction in air pollution. In total eight damages components of air pollution are considered namely mortality, incidence of bronchitis, asthma, minor health symptoms, visibility loss, material damages, damages to historical buildings and monuments and ecosystems damages. The payment vehicle used was a one-time increase in taxes. Data collection based on face to face interviews with 1,055 people. Results indicated that the total value as a fraction of GDP per capita in Poland was $0.77 \%$ for a $25 \%$ pollution reduction and $0.96 \%$ for a $50 \%$ reduction.

In the developing world a large number of contingent valuation studies addressing air pollution and either averted mortality or averted morbidity due to air pollution mitigation strategies have been conducted. In Taiwan these issues are addressed through contingent valuation by Alberini et al. (1997). The study of Alberini et al. (1997) demonstrates a contingent valuation exercise in three cities of Taiwan (Taipei, Kaohsiung and Hualien). In this study, people instead of being asked to state their WTP for a specified type of illness already defined for them, are asked to value their own illness experience and report their WTP to avoid it. The main advantage of that valuation design is that people are familiar with the commodity to be valued. Estimated WTP (in 1992 US\$) to avoid an entire episode of cold is $\$ 20.45$ for 1-day episode and $\$ 34.62$ for a 5-day episode. If the episode is not cold 
WTP is $\$ 30.73$ and $\$ 52.01$ respectively. Authors concluded that willingness to pay to avoid a day of illness is higher for a 1-day episode than for each day of a 5-day episode. Also the nature of the illness (i.e. cold or other) significantly affects WTP values. Another example of a contingent valuation in Taiwan can be found by Alberini \& Krupnick (2000) who estimate willingness to pay to avoid minor respiratory illnesses associated with air pollution. Chestnut et al. (1997) investigate the benefits to human health due to reductions in particulate air pollution. In their study can be found summarized the results from a number economic valuation studies conducted in Bangkok. In this study WTP estimates from Bangkok are compared with US estimates in order to examine the transferability of air pollution control health benefits from the United States to developing countries. Authors concluded that Bangkok residents are willing to pay a higher share of their income to protect their health.

Mortality and morbidity effects of air pollution have been extensively studied through contingent valuation in China (Hammit \& Zhou, 2006; Wang H. \& Mullahy, 2006; and Wang Y. \& Zhang, 2009). Hammit \& Zhou (2006) employed a contingent valuation to estimate the economic value of air pollution related health risks in three diverse locations in China. This study is recognized as the first organized and peer-reviewed CV study on health effects in China. Authors valued colds, bronchitis and mortality related to air pollution. Sample's average median WTP to prevent an episode of cold ranges between US\$3 and US\$6, WTP to prevent a statistical case of chronic bronchitis ranges between US\$500 and US\$1000 and the value of statistical life ranged between US\$4000 and US\$17000.

Wang Y. \& Zhang (2009) implement a contingent valuation exercise to quantify individuals' willingness to pay for improved air quality in the city of Ji'nan, China. A stratified sample of 1500 residents was chosen and WTP was elicited by conducting face to face interviews employing a series of hypothetical, open ended scenario questions. Almost $60 \%$ of respondents expressed a positive willingness to pay, WTP estimated at 100 Chinese Yuan per person, per year. Debriefing questions revealed that most respondents regard air quality improvement as a government responsibility, $40 \%$ of the respondents had no incentive to bear the costs of attempting better air quality, indicating a relatively low environmental consciousness.

Wang H. \& Mullahy (2006) employed a contingent valuation method in an attempt to estimate the value of statistical life, i.e. the willingness to pay for reducing fatal risk by improving air quality in Chongqing, China. A sample of 500 respondents selected based on multistage sampling methods. Face to face interviews and a series of hypothetical open ended scenarios are employed to elicit WTP for air pollution reductions. WTP to save one statistical life estimated to be $\$ 34,458$ while the mean annual income is $\$ 490$. Interesting finding of this study is that people in China, unlike other developed countries, appear to consider clean air a luxury good.

Choice experiment currently offers the most promising approach to value non-marketed environmental goods. Even though this technique has been widely applied for the valuation of other environmental resources and services, the use of choice experiment on air pollution valuation literature is still limited. Rodriguez \& Leon (2004) performed a choice experiment in Las Palmas Grand Canaria, Spain focusing on health effects caused by emissions from a large power plant. The policy measure to be valued involves the installation of filters that reduce emissions of particulates and other gases that cause adverse health effects. Installation would reduce the probability of becoming ill or suffering some episode of respiratory illness. A sample of 350 persons was randomly selected from the population and data collected through face to face interviews. Results showed that policy proposal would 
benefit people in the polluted suburb. Paternalistic altruism appeared to be present and significant for the large majority of the sample.

Banfi et al. (2007) attempted to estimate the benefits of an increase in local environmental quality in the Swiss cities of Zurich and Lugano by conducting a web-based choice experiment. In particular authors examine the impact of air pollution externalities on the rent for dwellings. Dataset comprise a representative sample of 394 households for Zurich and 241 households for Lugano. In each choice set respondents were asked to choose between three alternatives scenarios with varying environmental characteristics including air quality and monthly rent. The last alternative represented current dwelling situation. Estimation results showed that levels of air pollution are important factor when choosing a dwelling. People showed a positive and significant WTP for an improvement of environmental quality in the both urban areas. Good air quality along with low traffic noise exposure, were the highest valued attributes.

A choice experiment is also applied by Yoo et al. (2008) in an attempt to quantify the environmental costs of four air pollution impacts (mortality, morbidity, soiling damage, and poor visibility) in Seoul, Korea. Authors consider the trade-offs between price and other attributes of air pollution impacts and derive the marginal willingness to pay (WTP) estimate for each attribute. According to the results, the households' monthly WTP for a $10 \%$ reduction in the concentrations of major pollutants in Seoul was found to be approximately 5494 Korean won and the total annual WTP for the entire population of Seoul was about 203.4 billion Korean won.

The determinant role of economic assessment in accounting external damage into policy design process or in project appraisal has already been mentioned. In the literature, economic valuation techniques have also been used to provide economics ground for supporting investments in air pollution abatement enabling the application of a cost benefit analysis (Aunan et al. 1998; Larson, 1999, Li et al., 2004; Miraglia, 2007).

Aunan et al. (1998) assessed the cost and benefits of the implementation of a specific energy saving program in Hungary. Authors considered the possible reduced damage to public health, building materials and agricultural crops that may be obtained from reducing emissions of important air pollutants. Also accounted how the program contributes to reduced emissions of greenhouse gases. Analysis indicated that the main benefits from reducing the pollutants' concentrations relate to public health. The estimated benefits emerged from improved health conditions alone appear to exceed the investment needed to implement the program. Another study that has focused on the energy emission has been conducted by Larson et al. (1999) who employed a cost benefit analysis to assess the efficiency of five projects that would lead to $25 \%$ reduction in mortality risk due to reductions in particulate emissions in Russia. Economic assessment of the projects revealed a positive net present benefit of $\$ 40$ million which justify the undertaking of the projects on economic ground. Miraglia, (2007) also performed a cost benefit analysis to assess the health, environmental and economic costs of the use of stabilized/ethanol mixture in the city of Sao Paolo. The quantitative environmental analysis resulted in a positive balance of US\$ 2.851 billion. Finally in the city of Shanghai in China Li et al. (2004) performed an illustrative cost benefit analysis to assess air pollution controls. Health benefits of pollution reduction are compared with investments costs of the new technology strategies in question. Benefit- cost ratio revealed that are considerable net benefits to be derived from the implementation of new technology in China. 
Sometimes in valuation exercises two different methods can be used. This gives the opportunity to researchers to compare the results obtained and test for the reliability of the valuation. Belhaz (2003) employed contingent valuation and hedonic price methods to estimate the benefits of clean air in Morocco from a 50\% reduction of air pollution caused by road traffic in Rabat-Sale. In the valuation literature, hedonic studies have been applied to estimate a relationship between housing prices and other attributes, including health risks associated with air pollution. The value people place on reduced health risks through improved air quality can be inferred by their WTP for houses with better air quality. The first application of hedonic pricing to demonstrate the effect of air pollution to the housing prices was conducted by Ridker \& Henning (1967) in USA. Results of that study indicated that air quality had a significant impact on housing prices. In particular it was estimated that reducing the sulphate level on $0.25 \mathrm{mg} /$ day increased the value of houses between $\$ 84$ and $\$ 245$ (in 1960). From that day many studies have used a hedonic approach to estimate the relationship between houses' prices and air pollution. Komarova (2009) aims to calculate implicit prices of the environmental level of air quality in the city of Moscow on the basis of housing property rights. Database used contained approximately 20 thousand apartments. Explanatory variables included physical characteristics of the houses, environmental, neighborhood, socio-demographic and geographic data. Hedonic analysis showed that ecological variable had a negative price while increasing the level of air contamination from carbon monoxide, nitrogen dioxide, sulphur dioxide and particles. Brucato et al (1990) and Won Kim et al. (2003) also applied hedonic pricing to isolate and measure the impact of air pollution. Smith \& Huang (1995) and Delucchi et al. (2002) performed a meta-analysis of cross sectional hedonic studies. Results indicate that hedonic price does not capture total health costs of air pollution because individuals are not fully informed about all of the health effects. Additionally the value of improved air quality is underestimated as this technique does not capture non use elements of value.

Other techniques have also being applied in the valuation literature of air pollution and human health. Hubbel (2006) implemented QALYs in the analysis of air pollution regulations. Precisely he explored the implications of the QALY approach to measure impacts of air pollution regulations, in particular US EPA Heavy Duty Engine/Diesel Fuel, and he investigated the potential use of QALY in cost-benefit analysis. Damigos (2005) used a damage cost approach to examine the implementation of a process that would reduce NOx emissions that are produced by the operation of an oil steam turbine power plant. Two alternatives are considered: a baseline do-nothing scenario, corresponding to $7332 \mathrm{tn} /$ year emissions of NOx, and a NOx emissions reduction scenario corresponding to $2985 \mathrm{tn} /$ year. The implementation of NOx reduction measures will result in an environmental improvement that is calculated at 3,350,000 euro per annum. Vrhovcak et al. (2005) used a damage cost method to estimate the damages to human health resulting from electricity production in Croatian thermal power plants. The following health end-points, were considered: acute mortality $(\$ 148,500)$, chronic mortality $(\$ 1,375,000)$, hospital treatment of cardiovascular diseases $(\$ 10,300)$, restricted activity days $(\$ 100)$, hospital treatment of respiratory diseases $(\$ 10,300)$, chronic bronchitis in children $(\$ 300)$ in adults $(\$ 138,000)$ and congestive heart failures in elder individuals $(\$ 10,300)$. In the brackets can be found the estimated total external costs i.e. the value of damage in 1995 US\$ from nine Croatian fossil fuel-fired power plants. Cesar et al. (2002) calculated the health benefits from a number of pollution reduction scenarios using appropriate dose response functions from the literature. 
Mexico City suffered from high levels of ozone and particulate pollution for years. Authors valued the avoided cases of morbidity and premature mortality by employing cost of illness and forgone earnings, willingness for avoided morbidity and willingness to pay for avoided mortality. Results suggest that a 10\% reduction in ozone was about $\$ 760$ million (in 1999 U.S. dollars) annually and the benefit for a 20\% reduction in ozone and PM was about $\$ 1.49$ billion annually. In India, Gupta (2006) employed a cost of illness approach to estimate the monetary benefits to individuals from health damages avoidance due to air pollution reductions. Health costs due to adverse effects of air pollution on health were considered as the sum of the loss in wages due to workdays lost and the expenditures made by households on mitigating activities. Murty et al. (2003) used household data to analyze the impact of higher levels of Suspended Particulate Matter (SPM) in the Indian metropolitan cities of Delhi and Kolkata. Health production function and demand functions for averting and mitigating activities were estimated. Study revealed that the annual marginal benefits to a typical household ranged from Rs 2086 in Delhi to Rs 950 in Kolkata if the level of SPM is reduced from current average level to the prescribed safe level.

Last, a body of research in economics employing self-reported happiness, or life satisfaction approach to examine the benefits that could be gained from higher levels of a non-marketed environmental good. Focusing in particular on air quality Welsch (2006) explores the relationship between air pollution and prosperity in ten European employing self reporting well being and it examines how well being varies with air quality and prosperity. The rate at which they trade off against each other is being calculated by measuring marginal disutility of pollution, as well as the marginal utility of income. It was found that a decrease in the $\mathrm{NO}_{2}$ concentrations is valued at $\$ 398$ per person per year in Greece up to $\$ 1858$ in Luxembourg (in 1997). Differences between values reflect the fact that people place more value on environmental improvement in richer than in poorer countries. In relative terms, the value of reduced $\mathrm{NO}_{2}$ ranges from $2.3 \%$ of per capita income (UK) up to $9.8 \%$ (Spain). With respect to lead concentrations, the estimated values ranging from $\$ 657$ (Greece) up to $\$ 3113$ (Denmark). The total value of air quality improvement $\left(\mathrm{NO}_{2}\right.$ and lead) ranges from $\$ 1076$ (Greece) up to $\$ 3859$ (Denmark) while the total value as a percentage of income ranges from $5.1 \%$ (Luxembourg) up to $18.2 \%$ (Denmark).

All studies mentioned have focused on ambient air quality. Very few valuation studies have investigated the benefits generated by improved indoor air quality. Chau et al. (2007) combined revealed and stated preferences techniques to estimate the monetary benefits gains from improved indoor air quality. It was found that significant gains are derived from an increase in indoor air quality.

\subsection{Air pollution ecosystems, buildings materials and cultural heritage}

It is well known that air pollution affects ecosystem's good and services. Many studies have attempted to impute a monetary value to these damages. MacMillan (2001) in a report prepared for DEFRA provides a review on the literature on ecosystem valuation in the context of air pollution and describes the main challenges confronting valuing ecosystems recovery. Author concluded that studies from North America and Scandinavia dominate the international literature on valuing ecosystems effects of air pollution. Most of these studies are concerned with impacts of air pollution on forest growth and timber. Concluding remark is that assessing the benefits of ecosystem recovery from air pollution is not a straightforward procedure. The main reason for this is the great uncertainty surrounding 
both future environmental damage of air pollution and future environmental recovery from air pollution reductions. Scientific understanding of the complex ecosystem function in many cases is very limited.

Contingent valuation can incorporate such issues of uncertainty. An example of a contingent valuation implementation in the ecosystem valuation literature is provided by Macmillan et al. (1996) who estimate willingness to pay of the Scottish population for uncertain recovery and damage scenarios from reduced acid rain deposition in the semi-natural uplands of Scotland. In order to deal with uncertainty, it has been used a split-sample survey format presenting six alternative ecosystem recovery levels and damage levels scenarios. Approximately 1000 households were sampled by mail. Average household WTP, elicited using a dichotomous choice format, for abatement of acid rain ranged from $£ 247$ to $£ 351$ depending on the scenario. WTP was statistical significantly influenced by the level of future damage but not by future recovery level.

Pollution and climatic parameters may also have a direct effect on several materials. Rabl (1999) value the damage to building materials linked to air pollution in France. Analysis provides estimates for the damage cost of air pollution on historical buildings focusing on the effects of acidic deposition on corrosion and deposition of soiling. Aunan et al. (1998) in a project assessment accounted for the effects of air pollution on buildings and indicated that there are significant benefits to be gained due to reduced replacement and maintenance costs for buildings materials (US\$ 30-35 million annually in Budapest only). Regarding cultural heritage, there can be found very few valuation studies undertaken. Yet historical heritage damages, as well as ecosystems damages, are important and the literature underestimates total damages by omitting them. Results from a Polish case study of Dziegielewska \& Mendelsohn (2005) showed that if these components were not valued, the results of that study would be underestimated by $13-16 \%$. Most of the studies tackling these issues are mainly employing a contingent valuation method (Pollicino \& Maddison, 2002; Morey et al., 2002; Navrud \& Strand, 2002). Pollicino \& Maddison (2002) performed a contingent valuation method to value aesthetic changes in the Lincoln Cathedral, UK due to air pollution, Morey et al. (2002) employed a contingent valuation to value acid deposition injuries to marble monuments in Washingtom, DC, and Navrud \& Strand (2002) employed a contingent valuation exercise to value the damages from air pollution on the Nidaros Cathedral in Norway. Even limited this part of the literature ought to be helpful to agencies and organizations whose mission is the protection and preservation of cultural heritage, i.e. historic buildings, monuments etc., from exposure to pollution. These studies provide public values for cultural heritage goods and can provide much information regarding social perceptions.

\section{The use of valuation results in policy design}

The strongest argument for assigning economic values is the use of valuation results in policy design. Theory underlies that if external effects are omitted from appraisal there is high risk that non-marketed goods will be under-supplied while non-marketed bad will be oversupplied. As it was mentioned in the first section of this chapter since the market mechanism is not able to capture the total value of environmental goods, public intervention is needed in order externalities be internalized into the decision process. It is important economic decisions to be made compatible with social objectives, i.e. efficiency and equity considerations. Preferences elicitation for different socio-economic groups and knowledge of 
the marginal valuation each group attaches to environmental improvements through valuation studies allows for equity considerations to be taken into account in the formulation of policy design (Remoundou \& Koundouri, 2009). Economic estimates give also information regarding the best use of available resources i.e. the option that has the lowest opportunity cost or the lowest value to be sacrificed. Monetary value assessment allows the ranking of alternative policy options through the implementation of cost-benefit analysis for policy guidance. There are many issues arising on how to introduce monetary valuation into public decision making. Pearce (2001) formulates some recommendations of getting CBA into the process of decision making. Monetary benefit estimates can serve many purposes. Bonnieux \& Rainelli, (1999) summarized the usefulness of valuation exercises. First of all valuation exercise can contribute to public debate and awareness concerning specific (environmental) problems. Translate environmental changes into money values can serve as a readily understandable indicator of environmental damage or potential benefits. Secondly monetary benefit estimates can influence particular decisions by employing a cost benefit analysis (or any other way of comparing costs and benefits). So the use of such estimates can help policy makers to identify the optimal alternative among competing options and to support and justify decisions taken by government agencies (Bonnieux \& Rainelli, 1999).

However limitations of the existing literature have been identified. The major obstacle that has restricted the use of benefits estimates is the uncertainty or the low credibility of the estimates. Responsible causes for this weakness can be: (Kuik et al. in Navrud, 1992)

1. Uncertainty about the most elementary physical dose-response relationship

2. Hypothetical character of the estimated money values.

3. Choice of the correct discount factor for discounting costs and benefits which occur on different points in time

4. Transboundary pollution problems and the choice of the relevant population affected in valuation exercise.

\section{Conclusion}

This review aimed to serve as a starting point for research on economic valuation estimates. It gives an elaborate cross-section of studies that are described in journals as well as studies financed by government agencies of which only reports are available. Findings of the literature indicate that society undertakes major benefits from reduction of air pollution level. Internationally the use of monetary valuation techniques in project appraisal has increased significantly. Techniques such as the contingent valuation which can estimate values for both users and non-users are being intensively used and are being constantly refined and extended. Findings of the literature review can be summarized in the followings:

- Studies of the developing world overweight number of studies conducted in developed countries.

- Limited application of choice experiment in health valuation studies related to air pollution.

- Limited number of studies assessing indoor air quality impacts on human health.

- Studies showed that are significant gains estimated to be derived from air pollution control instruments.

- Multidisciplinary research and close collaboration between economists and other scientists must be promoted in order more credible economic estimates to be produced. 
- $\quad$ The use of hedonic pricing underestimates values generated by improved air quality as it fails to capture non use elements of value.

- Improve scientific information is needed in order to be able to produce more reliable dose - response functions and thus more credible economic estimates of the values.

- Effects of air pollution on ecosystems and cultural heritage appear to be a significant damage to the society. Omitting these components of damage would result to a backwards bias in the estimates.

- Recent years have seen a growing interest in the potential of producing generally applicable estimates for the valuation of non-marketed environmental goods to another policy site. Many studies have addressed these issues and have tested the validity of benefit transfers. Meta-analysis of the existing results is another common application.

It follows a table summarizing valuation studies mentioned in this chapter.

\begin{tabular}{|c|c|c|c|c|}
\hline Authors & Study Area & $\begin{array}{l}\text { Valuation } \\
\text { Technique }\end{array}$ & $\begin{array}{c}\text { Environmental Impact / } \\
\text { Good to be Valued }\end{array}$ & Results \\
\hline $\begin{array}{l}\text { Carlson \& } \\
\text { Johansson - } \\
\text { Stenman, } \\
(2000)\end{array}$ & Sweden & $\begin{array}{l}\text { Contingent } \\
\text { Valuation }\end{array}$ & $\begin{array}{l}\text { Benefits from improved } \\
\text { air quality }\end{array}$ & $\begin{array}{l}\text { WTP for a } 50 \% \\
\text { reduction of harmful } \\
\text { substances where the } \\
\text { respondents live and } \\
\text { work estimated at } \\
\text { about } 2000 \text { SEK/year }\end{array}$ \\
\hline Navrud, (2001) & Norway & $\begin{array}{l}\text { Contingent } \\
\text { Valuation }\end{array}$ & $\begin{array}{l}\text { Air pollution and } \\
\text { human morbidity: } \\
\text { seven lights health } \\
\text { symptoms and asthma. }\end{array}$ & $\begin{array}{l}\text { Authors produced } \\
\text { mean WTP estimates } \\
\text { for the avoidance of } 1 \\
\text { and } 14 \text { additional days } \\
\text { 'light' health } \\
\text { symptoms per year. }\end{array}$ \\
\hline $\begin{array}{l}\text { Halvoren B. } \\
\text { (1996) }\end{array}$ & Norway & $\begin{array}{l}\text { Contingent } \\
\text { valuation }\end{array}$ & $\begin{array}{l}\text { Health benefits from a } \\
\text { decline in air pollution } \\
\text { due to reduced } \\
\text { emissions from traffic. }\end{array}$ & $\begin{array}{l}\text { WTP for a } 50 \% \\
\text { reduction in air } \\
\text { pollution estimated at } \\
1250 \text { SEK/year and } \\
\text { person. }\end{array}$ \\
\hline $\begin{array}{c}\text { Dziegielewska } \\
\& \\
\text { Mendelsohn, } \\
\text { (2005) }\end{array}$ & Poland & $\begin{array}{l}\text { Contingent } \\
\text { Valuation }\end{array}$ & $\begin{array}{l}\text { Adverse impact of air } \\
\text { pollution on } \\
\text { Health: mortality, } \\
\text { incidence of bronchitis, } \\
\text { asthma, minor health } \\
\text { symptoms; } \\
\text { Visibility loss, } \\
\text { Material damages to } \\
\text { historical buildings and } \\
\text { Ecosystems damages }\end{array}$ & $\begin{array}{l}\text { Authors produced } \\
\text { WTP estimates for a } \\
50 \% \text { reduction and a } \\
25 \% \text { reduction in air } \\
\text { pollution. Also } \\
\text { estimated damage of } \\
\text { air pollution as a } \\
\text { fraction of the GDP. } \\
\text { Historical heritage and } \\
\text { ecosystem damage } \\
\text { appeared to be } \\
\text { significant components } \\
\text { of total damage }\end{array}$ \\
\hline
\end{tabular}




\begin{tabular}{|c|c|c|c|c|}
\hline Authors & Study Area & $\begin{array}{l}\text { Valuation } \\
\text { Technique }\end{array}$ & $\begin{array}{l}\text { Environmental Impact / } \\
\text { Good to be Valued }\end{array}$ & Results \\
\hline $\begin{array}{l}\text { Desaigues et } \\
\text { al. (2004) }\end{array}$ & France & $\begin{array}{l}\text { Contingent } \\
\text { Valuation }\end{array}$ & $\begin{array}{c}\text { Air Pollution and } \\
\text { Human }\end{array}$ & $\begin{array}{l}\text { Annual WTP for the } \\
\text { next } 10 \text { years for a } \\
\text { medical treatment that } \\
\text { would reduce the risk } \\
\text { of dying by } 1 \text { in } 1000 \text { is } \\
412 € \text { and by } 5 \text { in } 1000 \text { is } \\
563 € \text {. }\end{array}$ \\
\hline \multirow{3}{*}{$\begin{array}{l}\text { Banfi et al., } \\
\quad(2007)\end{array}$} & \multirow{3}{*}{$\begin{array}{l}\text { Zurich and } \\
\text { Lugano }\end{array}$} & \multirow{3}{*}{$\begin{array}{c}\text { Choice } \\
\text { experiment }\end{array}$} & \multirow{3}{*}{$\begin{array}{l}\text { Impact of air pollution } \\
\text { externalities on human } \\
\text { welfare. } \\
\text { Noise pollution and } \\
\text { electro smog were also } \\
\text { included into the } \\
\text { analysis }\end{array}$} & $\begin{array}{l}\text { Mean WTP for air } \\
\text { quality improvements } \\
\text { from bad to good is } 198 \\
\text { in Zurich and } 151 \text { in } \\
\text { Lugano (in CHF per } \\
\text { month) }\end{array}$ \\
\hline & & & & $\begin{array}{l}\text { Mean WTP for air } \\
\text { quality improvements } \\
\text { from bad to medium is } \\
198 \text { in Zurich and } 94 \text { in } \\
\text { Lugano (in CHF per } \\
\text { month) }\end{array}$ \\
\hline & & & & $\begin{array}{l}\text { Mean WTP air quality } \\
\text { improvements from } \\
\text { medium to good is } 70 \text { in } \\
\text { Zurich and } 57 \text { in } \\
\text { Lugano (in CHF per } \\
\text { month) }\end{array}$ \\
\hline $\begin{array}{l}\text { Rodriguez \& } \\
\text { Leon, (2004) }\end{array}$ & $\begin{array}{c}\text { Grand } \\
\text { Canaries, } \\
\text { Spain }\end{array}$ & $\begin{array}{l}\text { Choice } \\
\text { Experiment }\end{array}$ & $\begin{array}{l}\text { Health impacts of } \\
\text { energy production }\end{array}$ & $\begin{array}{l}\text { Results showed that } \\
\text { people would benefit } \\
\text { from the installation of } \\
\text { filters that reduce } \\
\text { particulate emissions. } \\
\text { Significant and } \\
\text { positive altruistic } \\
\text { values }\end{array}$ \\
\hline $\begin{array}{l}\text { Yoo et al. } \\
\text { (2008) }\end{array}$ & Seoul & $\begin{array}{c}\text { Choice } \\
\text { Experiment }\end{array}$ & $\begin{array}{l}\text { Environmental costs of } \\
\text { air pollution impacts } \\
\text { (mortality, morbidity, } \\
\text { soiling damages and } \\
\text { poor visibility) }\end{array}$ & $\begin{array}{l}\text { Households' monthly } \\
\text { WTP for a } 10 \% \\
\text { reduction in the } \\
\text { concentrations of } \\
\text { major pollutants was } \\
\text { approximately } 5494 \\
\text { Korean won. Total } \\
\text { annual WTP for the } \\
\text { entire population was } \\
\text { about } 203.4 \text { billion } \\
\text { Korean won }\end{array}$ \\
\hline
\end{tabular}




\begin{tabular}{|c|c|c|c|c|}
\hline Authors & Study Area & $\begin{array}{l}\text { Valuation } \\
\text { Technique }\end{array}$ & $\begin{array}{c}\text { Environmental Impact / } \\
\text { Good to be Valued }\end{array}$ & Results \\
\hline $\begin{array}{c}\text { Wang H. \& } \\
\text { Mullahy (2006) }\end{array}$ & China & $\begin{array}{l}\text { Contingent } \\
\text { Valuation }\end{array}$ & $\begin{array}{l}\text { Reduced fatal risk by } \\
\text { improving air quality }\end{array}$ & $\begin{array}{l}\text { Value of statistical life } \\
\text { estimated to be } \$ 34,468\end{array}$ \\
\hline $\begin{array}{c}\text { Wang Y. \& } \\
\text { Zhang, (2009) }\end{array}$ & China & $\begin{array}{l}\text { Contingent } \\
\text { Valuation }\end{array}$ & $\begin{array}{l}\text { Effects of air pollution } \\
\text { on human health }\end{array}$ & \begin{tabular}{|l|} 
Mean WTP was \\
estimated at 100 \\
Chinese yan per \\
person per year \\
\end{tabular} \\
\hline $\begin{array}{l}\text { Hammit \& } \\
\text { Zhou, (2006) }\end{array}$ & $\begin{array}{c}\text { Three } \\
\text { diverse } \\
\text { locations in } \\
\text { China }\end{array}$ & $\begin{array}{l}\text { Contingent } \\
\text { Valuation }\end{array}$ & $\begin{array}{l}\text { Benefits from improved } \\
\text { air quality }\end{array}$ & $\begin{array}{l}\text { Median WTP to } \\
\text { prevent an episode of } \\
\text { cold ranges between } \\
\text { US\$3 and US\$6, WTP } \\
\text { to prevent a statistical } \\
\text { case of chronic } \\
\text { bronchitis ranges } \\
\text { between US\$500 and } \\
\text { US\$1000 and the value } \\
\text { of statistical life ranged } \\
\text { between US\$4000 and } \\
\text { US\$17000. }\end{array}$ \\
\hline Belhaz, (2003) & Morocco & \begin{tabular}{|c|} 
Contingent \\
Valuation \\
and Hedonic \\
Pricing \\
\end{tabular} & $\begin{array}{l}\text { Air pollution road traffic } \\
\text { Benefits from clean air }\end{array}$ & $\begin{array}{l}\text { Authors produce WTP } \\
\text { estimates for a } 50 \% \\
\text { reduction of air } \\
\text { pollution }\end{array}$ \\
\hline $\begin{array}{l}\text { Alberini et al., } \\
\text { (1997) }\end{array}$ & $\begin{array}{c}\text { Three cities } \\
\text { of Taiwan }\end{array}$ & $\begin{array}{l}\text { Contingent } \\
\text { Valuation }\end{array}$ & $\begin{array}{c}\text { Air Pollution - Human } \\
\text { Health }\end{array}$ & $\begin{array}{l}\text { Authors produce WTP } \\
\text { to avoid the recurrence } \\
\text { of an episode of minor } \\
\text { respiratory illness } \\
\text { identical to that most } \\
\text { recently experienced } \\
\text { by the respondent }\end{array}$ \\
\hline $\begin{array}{l}\text { Alberini \& } \\
\text { Krupnick, } \\
\quad(2000)\end{array}$ & Taiwan & $\begin{array}{l}\text { Contingent } \\
\text { Valuation }\end{array}$ & $\begin{array}{l}\text { Air Pollution } \\
\text { Human Health }\end{array}$ & $\begin{array}{l}\text { Authors produced } \\
\text { WTP estimates to } \\
\text { avoid minor } \\
\text { respiratory illnesses } \\
\text { associated with air } \\
\text { pollution. }\end{array}$ \\
\hline $\begin{array}{c}\text { Chestnut et al., } \\
\text { (1997) }\end{array}$ & Bangkok & $\begin{array}{l}\text { Contingent } \\
\text { Valuation }\end{array}$ & $\begin{array}{c}\text { Benefits to human health } \\
\text { due to reductions in } \\
\text { particulate pollution }\end{array}$ & $\begin{array}{l}\text { Authors produce WTP } \\
\text { estimates to avoid three } \\
\text { minor respiratory } \\
\text { health endpoints } \\
\text { characterized by } \\
\text { different severity: one- } \\
\text { symptom day, one } \\
\text { restricted activity day } \\
\text { and one work-loss day. }\end{array}$ \\
\hline
\end{tabular}




\begin{tabular}{|c|c|c|c|c|}
\hline Authors & Study Area & $\begin{array}{l}\text { Valuation } \\
\text { Technique }\end{array}$ & $\begin{array}{c}\text { Environmental Impact / } \\
\text { Good to be Valued }\end{array}$ & Results \\
\hline Li et al., (2004) & Shnaghai & $\begin{array}{l}\text { Cost Benefit } \\
\text { Analysis }\end{array}$ & $\begin{array}{l}\text { Health benefits from } \\
\text { pollution reduction }\end{array}$ & $\begin{array}{l}\text { Benefit cost ratio } \\
\text { revealed considerable } \\
\text { net benefits to be } \\
\text { derived }\end{array}$ \\
\hline Gupta, (2006) & India & $\begin{array}{l}\text { Cost of } \\
\text { illness }\end{array}$ & $\begin{array}{c}\text { Monetary benefits to } \\
\text { individuals from } \\
\text { avoided health damages } \\
\text { due to reductions in air } \\
\text { pollution }\end{array}$ & $\begin{array}{l}\text { Results indicated that } \\
\text { the mean worker from } \\
\text { Kanpur would gain Rs } \\
165 \text { per year if air } \\
\text { pollution were } \\
\text { reduced to a safe level }\end{array}$ \\
\hline Welsch, (2006) & $\begin{array}{l}10 \\
\text { European } \\
\text { Countries }\end{array}$ & $\begin{array}{l}\text { Life } \\
\text { satisfaction } \\
\text { approach }\end{array}$ & $\begin{array}{l}\text { Effect of air pollution on } \\
\text { well- being }\end{array}$ & $\begin{array}{l}\text { It was found that a } \\
\text { decrease in the } \mathrm{NO}_{2} \\
\text { concentrations is } \\
\text { valued at } \$ 398 \text { per } \\
\text { person per year in } \\
\text { Greece up to } \$ 1858 \text { in } \\
\text { Luxembourg (in 1997). }\end{array}$ \\
\hline Rabl, (1999) & France & $\begin{array}{l}\text { Damage } \\
\text { Cost }\end{array}$ & $\begin{array}{l}\text { Ambient Air Pollution } \\
\text { and Historical Buildings }\end{array}$ & $\begin{array}{l}\text { Analysis provides } \\
\text { estimates for the } \\
\text { damage cost of air } \\
\text { pollution on historical } \\
\text { buildings focusing on } \\
\text { the effects of acidic } \\
\text { deposition on } \\
\text { corrosion and } \\
\text { deposition of soiling. }\end{array}$ \\
\hline $\begin{array}{l}\text { Chilton et al., } \\
\qquad(2004)\end{array}$ & UK & $\begin{array}{l}\text { Contingent } \\
\text { Valuation }\end{array}$ & $\begin{array}{c}\text { Health benefits of } \\
\text { improved air pollution } \\
\text { in terms of mortality and } \\
\text { morbidity }\end{array}$ & $\begin{array}{l}\text { The mean annual } \\
\text { WTP for chronic } \\
\text { mortality is £ } 29.52 \\
\text { for the one month } \\
\text { sample, } £ 30.21 \text { for the } \\
\text { three months sample } \\
\text { and } £ 38.73 \text { for the six } \\
\text { month sample. }\end{array}$ \\
\hline $\begin{array}{l}\text { Larson et al., } \\
\qquad(1999)\end{array}$ & Russia & $\begin{array}{l}\text { Value of a } \\
\text { Statistical } \\
\text { Life/Cost- } \\
\text { Benefit } \\
\text { Analysis }\end{array}$ & $\begin{array}{l}\text { Particulate emissions } \\
\text { and mortality }\end{array}$ & $\begin{array}{l}\text { Economic assessment } \\
\text { revealed a positive net } \\
\text { benefit of } \$ 40 \text { million }\end{array}$ \\
\hline $\begin{array}{l}\text { Damigos, } \\
\text { (2005) }\end{array}$ & $\begin{array}{l}\text { Crete, } \\
\text { Greece }\end{array}$ & $\begin{array}{l}\text { Damage } \\
\text { Costs }\end{array}$ & Air Pollution - energy & $\begin{array}{l}\text { Environmental } \\
\text { improvement due to } \\
\text { reduced NOx } \\
\text { emissions calculated at } \\
3.350 .000 € \text { per year }\end{array}$ \\
\hline
\end{tabular}




\begin{tabular}{|c|c|c|c|c|}
\hline Authors & Study Area & $\begin{array}{l}\text { Valuation } \\
\text { Technique }\end{array}$ & $\begin{array}{l}\text { Environmental Impact / } \\
\text { Good to be Valued }\end{array}$ & Results \\
\hline $\begin{array}{c}\text { Aunan et al., } \\
\text { (1998) }\end{array}$ & Hungary & $\begin{array}{c}\text { Cost-Benefit } \\
\text { Analysis }\end{array}$ & $\begin{array}{l}\text { Air Pollution and public } \\
\text { health, buildings } \\
\text { materials and } \\
\text { agricultural crops }\end{array}$ & $\begin{array}{l}\text { Estimated annual } \\
\text { benefits of improved } \\
\text { health conditions } \\
\text { exceeds the } \\
\text { investments needed }\end{array}$ \\
\hline $\begin{array}{l}\text { Miraglia, } \\
\text { (2007) }\end{array}$ & Brazil & $\begin{array}{c}\text { Cost-Benefit } \\
\text { Analysis }\end{array}$ & Air Pollution & $\begin{array}{l}\text { Quantitative } \\
\text { environmental } \\
\text { analysis resulted in a } \\
\text { positive balance of } \\
\text { 2851US\$ }\end{array}$ \\
\hline $\begin{array}{c}\text { Vrhovcak et } \\
\text { al., (2005) }\end{array}$ & Croatia & Damage cost & $\begin{array}{l}\text { External costs of } \\
\text { electricity generation in } \\
\text { terms of human health }\end{array}$ & $\begin{array}{l}\text { Authors estimated } \\
\text { external cost for a } \\
\text { bundle of health } \\
\text { endpoints }\end{array}$ \\
\hline $\begin{array}{l}\text { Cesar et al., } \\
\quad(2002)\end{array}$ & Mexico & $\begin{array}{l}\text { Dose - } \\
\text { response } \\
\text { functions/ } \\
\text { Cost of } \\
\text { Illness }\end{array}$ & $\begin{array}{l}\text { Health benefits from a } \\
\text { number of pollution } \\
\text { reduction scenarios }\end{array}$ & $\begin{array}{l}\text { Results suggest that a } \\
10 \% \text { reduction in } \\
\text { ozone was about } \$ 760 \\
\text { million (in } 1999 \text { U.S. } \\
\text { dollars) annually and } \\
\text { the benefit for a } 20 \% \\
\text { reduction in ozone and } \\
\text { PM was about } 1.49 \\
\text { billion annually. }\end{array}$ \\
\hline $\begin{array}{l}\text { Murty et al. } \\
\text { (2003) }\end{array}$ & $\begin{array}{l}\text { Delhi and } \\
\text { Kolkata }\end{array}$ & $\begin{array}{c}\text { Health } \\
\text { production } \\
\text { functions } \\
\text { and demand } \\
\text { functions for } \\
\text { averting and } \\
\text { mitigating } \\
\text { activities }\end{array}$ & Air pollution & $\begin{array}{l}\text { Annual marginal } \\
\text { benefits to a typical } \\
\text { household ranged } \\
\text { from Rs } 2086 \text { in Delhi } \\
\text { to Rs } 950 \text { in Kolkata if } \\
\text { the level of SPM is } \\
\text { reduced from current } \\
\text { average level to the } \\
\text { prescribed safe level. }\end{array}$ \\
\hline $\begin{array}{l}\text { Komavora, } \\
(2009)\end{array}$ & Moscow & $\begin{array}{l}\text { Hedonic } \\
\text { pricing }\end{array}$ & $\begin{array}{c}\text { Relationship between air } \\
\text { pollution and housing } \\
\text { prices }\end{array}$ & $\begin{array}{l}\text { Ecological variable had } \\
\text { a negative sign while } \\
\text { increasing the level of } \\
\text { air contamination from } \\
\text { carbon monoxide, } \\
\text { nitrogen dioxide, } \\
\text { sulphur dioxide and } \\
\text { particles. }\end{array}$ \\
\hline $\begin{array}{c}\text { MacMillan, } \\
\text { (1996) }\end{array}$ & Scotland & $\begin{array}{l}\text { Contingent } \\
\text { Valuation }\end{array}$ & $\begin{array}{l}\text { Effect of reduced acid } \\
\text { rain deposition in the } \\
\text { ecosystems }\end{array}$ & $\begin{array}{l}\text { Average WTP ranged } \\
\text { from } £ 247 \text { to } £ 351 \\
\text { depending on the } \\
\text { scenario }\end{array}$ \\
\hline
\end{tabular}




\begin{tabular}{|c|c|c|c|c|}
\hline Authors & Study Area & $\begin{array}{l}\text { Valuation } \\
\text { Technique }\end{array}$ & $\begin{array}{l}\text { Environmental Impact / } \\
\text { Good to be Valued }\end{array}$ & Results \\
\hline $\begin{array}{l}\text { Pollicino \& } \\
\text { Maddisson, } \\
(2002)\end{array}$ & $\begin{array}{l}\text { Lincoln } \\
\text { Cathedral, } \\
\text { UK }\end{array}$ & $\begin{array}{l}\text { Contingent } \\
\text { Valuation }\end{array}$ & $\begin{array}{l}\text { Aesthetic changes on } \\
\text { historical buildings due } \\
\text { to air pollution }\end{array}$ & \multirow{3}{*}{$\begin{array}{l}\text { All studies produced } \\
\text { WTP estimates for a } \\
\text { policy option that } \\
\text { would reduce harmful } \\
\text { pollutants }\end{array}$} \\
\hline $\begin{array}{l}\text { Morey et al., } \\
\text { (2002) }\end{array}$ & Washington & $\begin{array}{l}\text { Contingent } \\
\text { Valuation }\end{array}$ & $\begin{array}{l}\text { Acid deposition injuries } \\
\text { to marble monuments }\end{array}$ & \\
\hline $\begin{array}{c}\text { Navrud \& } \\
\text { Strand, (2002) }\end{array}$ & $\begin{array}{l}\text { Nidaros } \\
\text { Cathedral, } \\
\text { Norway }\end{array}$ & $\begin{array}{l}\text { Contingent } \\
\text { Valuation }\end{array}$ & $\begin{array}{c}\text { Air pollution and } \\
\text { damages to buildings }\end{array}$ & \\
\hline
\end{tabular}

Table 1. Summary of the Valuation Studies

\section{References}

Alberini, A.; Cropper, M.; Fu, T.T.; Krupnick, A.; Liu, J.T.; Shaw, D. \& Harrington, W. (1997). Valuing health effects of air pollution in Developing countries: the Taiwan experience. Journal of Environmental Economics and Management, Vol. 34, pp. 107-26

Alberini, A. \& Krupnick, A. (2000). Cost of Illness and Willingness to Pay estimates of the Benefits of Improved Air Quality: Evidence from Taiwan. Journal of Land Economics, Vol. 76, No.1, pp. 37-53

Arrow, K.; Solow, R.; Portney, P.R.; Leamer, E.E \& Radner, R.H. (1993). Report on the NOOA Panel on contingent valuations, natural resource damage assessment under the oil pollution act of 1990. Federal Register, Vol. 58 pp. 4601-4614

Aunan, K.; Patzay, G.; Aaheim, H.A. \& Seip, H.M. (1998). Health and Environmental Benefits from Air Pollution Reductions in Hungary. The Science of the Total Environment Vol. 212, pp. 245-268

Banfi, S.; Filippini, M. \& Horehajova, A. (2007). Using a Choice Experiment to Estimate the Benefits of a Reduction in Externalities in Urban Areas with Special Focus on Electrosmog. Centre for Energy Policy and Economics (CEPE), Working Paper No. 57, ETH (Swiss Federal Institute of Technology), Zurich

Bateman, I.; Carson, R.; Day, B.; Hanemann, M.; Hanley, N.; Hett, T.; Jones-Lee, M.; Loomes, G.; Mourato, S.; Ozdemiroglu, E.; Pearce, D.; Sugden, R. \& Swanson, J. (2002) Economic Valuation with Stated Preferences Techniques: A manual. Cheltenham, Edward Elgar, ISBN:9781840649192

Belhaj, M. (2003). Estimating the benefits of clean air; Contingent valuation and hedonic price methods. International Journal of Global Environmental Issues, Vol. 3, No. 1, pp. $30-46$

Bell, M.L.; Davis, D.L.; Cifuentes, L.A.; Krupnick, A.J; Morgenstern, R.D. \& Thurston, G.D. (2008). Ancillary human health benefits of improved air quality resulting from climate change mitigation. Journal of Environmental Health Vol. 7, No. 41

Brucato, P.F.; Murdoch, J.C. \& Thayer, M.A. (1990). Urban Air Quality Improvements: a Comparison of Aggregate Health and Welfare Benefits to Hedonic Price Differentials. Journal of Environmental Management Vol. 30, No. 3, pp. 265-279

Bonniex, F. \& Rainelli, P. (1999). Contingent Valuation Methodology and the EU institutional framework. In Bateman, I.J., Willis, K.G. (eds.) Valuing environmental preferences, Theory and practice of the contingent valuation method in the US, EU and Developing Countries. New York, Oxford University Press pp. 585-612 
CAFÉ (2005) Commission Staff Working Paper, Annex to: The Communication on Thematic Strategy on Air Pollution, and the Directive on Ambient Air Quality and Cleaner Air for Europe, SEC (2005) 1133

Carlsson, F. \& Johansson-Stenman, O. (2000). Willingness to pay for improved air quality in Sweden. Journal of Applied Economics Vol. 32, pp. 661-669

Cesar, H.; Borja-Aburto, V.H.; Dorland, K.; Munoz Cruz, R.; Brander, L.; Cropper, M.; et al. (2002). Improving air quality in metropolitan Mexico City: an economic valuation, Policy Research Working Paper Series 2785, The World Bank, Washington, DC

Chau, C.K.; Hui, W.K. \& Tse, M.S. (2007). Evaluation of health benefits for improving indoor air quality in workplace. Environment International, Vol. 33, No.2, pp. 186-198

Chestnut, L.G.; Ostro, B.D. \& Vichit-Vadakan N. (1997). Transferability of Air Pollution Control Health Benefits Estimates from the United States to Developing countries: Evidence from the Bangkok study. American Journal of Agricultural Economics, Vol. 79, pp. 1630-1635

Chilton, S.; Covey, J.; Jones-Lee, M.; Loomes, G. \& Metcalf, H. (2004). Valuation of health benefits associated with reductions in air pollution, final report; Department for Environment Food and Rural Affairs, London, UK.

EXTERNE (2005). Externalities of Energy. Methodology 2005 Update Bickel P. and Friedrich R. (eds), European Commission, EUR 21951 ISBN 92-79-00423-9

Damigos, D. (2005). Economic aspects and environmental cross-media effects in energy production. WSEAS Int. Conference: Energy, Environment, Ecosystems, Sustainable Development, Vouliagmeni Greece, IASME Transactions Vol. 3, No. 2, pp. 325-330

Delucchi, M.A.; Murphy, J.J. \& McCubbin, D.R. (2002). The health and visibility costs of air pollution: a comparison of estimation methods. Journal of Environmental Management Vol. 64 pp. 139-152

Desaigues, B; Rabl, A; Ami, D.; My, K.B.; Masson, S.; Salomon, M.A.\& Santoni, L. (2004). Monetary valuation of air pollution mortality: current Practice, Research Needs and Lessons from a Contingent valuation. Universite de Strasbourg, Strasbourg, Alsace, France

Dziegielewska, D. \& Mendelsohn, R. (2005). Valuing air quality in Poland. Journal of Environmental and Resources Economics, Vol. 30, No.2, pp. 131-163

Gupta, U. (2006). Valuation of urban air pollution: a case study of Kanpur in India. SANDEE Working Paper No. 17-06, South Asian Network for Development and Environmental Economics (SANDEE), Kathmandu, Nepal

Halvoren, B. (1996). Ordering effects in contingent valuation surveys: Willingness to pay for reduced health damage from air pollution. Journal of Environmental and Resources Economics, Vol. 8, pp. 485-99

Hammit, J. K. (2002). QALYs vs WTP. Journal of Risk Analysis, Vol. 22, No.5, pp. 985-1001

Hammit, J.K. \& Zhou, Y. (2006). The economic value of air pollution related health risks in China: a contingent valuation study. Journal of Environmental and Resource Economics, Vol. 33, No. 3, pp. 399-423

Hubbell, B.J. (2006). Implementing QALYs in the Analysis of Air Pollution Regulations. Journal of Environmental and resources Economics, Vol. 34, No. 3, pp. 365-384

Karousakis, K. \& Koundouri, P. (2006). A Typology of Economic Instruments and Methods for Efficient Water Resources Management in Arid and Semi-Arid Regions, in Water Management in Arid and Semi-Aid Regions: Interdisciplinary Perspectives. Edward-Elgar Publishing, p. 161-187

Katsouyanni, K. (2003). Ambient air pollution and health. British Medical Bulletin Vol. 68, No. 1 , pp. $143-156$ 
Komavora, V. (2009). Valuing Envirnmental Impact of Air Pollution in Moscow with Hedonic Prices. World Academy of Science, Engineering and Technology, Vol. 7, pp. 319-326

Krupnick, A.; Alberini, A.; Cropper, M.; Simon, N.; O’Brien, B.; Ron Goeree, R. \& Heintzelman, M. (2002). Age, Health and the Willingness to Pay for Mortality Risks reductions: A Contingent Valuation Survey of Ontario Residents. Journal of Risk and Uncertainty Vol. 24, No. 2, pp. 161-186

Kuik, O.; Navrud, S. \& Pearce, D.W. (1992). Benefit estimation and environmental decision making. In Navrud S. (eds), Pricing the European Environment, Oslo, Scandinavian University Press

Larson, B.A.; Avaliani, S.; Golub, A.; Rosen, S.; Shaposhnikov, D.; Strukova, E.; Vincent, J.R. \& Wolff, S.K. (1999). The economics of air pollution health risks in Russia: a case study of Volgograd. World Development Vol. 27, No.10, pp. 1803-1819

Li, J.; Guttikunda, S.K.; Carmichael, G.R; Streets, D.G; Chang, Y-S. \& Fung, V. (2004). Quantifying the human health benefits of curbing air pollution in Shanghai. Journal of Environmental Management Vol. 70, No.1, pp. 49-62

Macmillan, D.; Hanley, N. \& Buckland, S. (1996). A Contingent Valuation Study of Uncertain Environmental Gains. Scottish Journal of Political Economy, Vol. 43, No. 5, pp. 519-533.

MacMillan, D. (2001) Valuation of Air Pollution Effects on Ecosystems: A Scoping study. A report prepared to the Department for Environment, Food and Rural Affairs. University of Aberdeen

Miraglia, S.G.E.K. (2007). Health, environmental and economic costs from the use of a stabilized diesel/ethanol mixture in the city of Sao Paolo. Cadernos de saude publica Vol. 23, pp. 559-569

Mitchell, R.C \& Carson, R. (1989). Using Surveys to Value Public Goods: The Contingent Valuation Method. Resources for the Future, Washington, D.C.

Morey, E.R.; Rossmann, K.G.; Chestnut, L.G. \& Ragland S. (2002). Valuing Reduced Acid Deposition Injuries to Cultural Resources: Marble Monuments in Washington, D.C. In Valuing Cultural Heritage: applying environmental techniques to historic buildings, monuments and artifacts, Navrud, S. \& Ready, R.C. (eds.) Cheltenham: Edward Elgar Publishing Limited, UK

Murty, M.N.; Gulati, S.C. \& Banerjee A. (2003). Health Benefits from Urban Air Pollution Abatement in the Indian Subcontinent. E/236/2003, Delhi: Institute of Economic Growth

Navrud, S. (2001).Valuing health impacts from air pollution in Europe. Journal of Environmental and Resources Economics, Vol. 20, No.4, pp. 305-329

Navrud, S. \& Strand, J. (2002). Social Costs and Benefits of Preserving and Restorig Nidaros Cathedral. In Valuing Cultural Heritage: applying environmental techniques to historic buildings, monuments and artifacts, Navrud, S. and Ready, R.C. (eds) pp. 31-39, Chentlenham: Edward Elgar Publishing Limited, UK, ISBN 1840640790

Navrud, S. (2004). Value transfer and environmental policy. In The International Yearbook of Environmental and Resources Economics 2004/2005: a survey of current issues Tietenberg, T and Folmer H. (eds.) Chapter 5, pp. 189-217 Edward Elgar Publishing, Cheltenham, UK and Northampton, MA, USA.

Pearce, D. (1996). Economic Valuation and Health Damage from Air Pollution in the Developing World. Energy Policy Vol. 24, No. 7, pp. 627-630.

Pearce D. (2001) Annex II: Integrating cost-benefit analysis into the policy process in Howarth, A., Pearce D.W., Ozdemiroglu, E., Seccombe-Hett, T., Wieringa, K., 
Streefkerk, C.M. de Hollander, A.E.M, RIVM report 481505024 Valuing the benefits of environmental policy: The Netherlands, Bilthhover, RIVM.

Pearce D.W. and Ozdemiroglu, E et al. (2002) Economic Valuation with Stated Preference Techniques. Summary Guide. Department for Transport, Local Government and the Regions: London, UK

Pollicino, M. \& Madisson, D. (2002). Valuing the Impacts of Air Pollution on Lincoln Cathedral. In Valuing Cultural Heritage: applying environmental techniques to historic buildings, monuments and artifacts. Navrud, S. and Ready, R.C. (eds) Chentlenham: Edward Elgar Publishing Limited

Rabl, A. (1999). Air pollution and Buildings: an Estimation of Damage Costs in France. Environmental Impact Assessment Review, Vol. 19, No. 4, pp. 361-385

Remoundou, K. \& Koundouri P. (2009). Environmental effects on public health: An economic perspective. International Journal of Environmental Research and Public Health, Vol.6, No.8, pp. 2160-2178

Ridker, R.G. \& Henning J. A. (1967). The determinants of residential property values with special reference to air pollution. The Review of Economic and Statistics, Vol. 49, No. 2, pp. 246-257

Smith, V.K \& Huang, J-C. (1995) Can Markets Value Air Quality? A Meta-Analysis of Hedonic Property Value Models. The Journal of Political Economy Vol. 103, No.1, pp. 209-227

Rodriguez, V. M. \& Leon, C. (2004). Altruism and the Economic Values of Environmental and Social Policies. Journal of Environmental and Resources Economics, Vol. 28, No.2, pp. 233-249.

Rosenber, R.S \& Loomis J.B. (2001). Benefit transfer of outdoor recreation use values: A technical document supporting the Forest Service Strategy Plan (2000 revision). RMRS-GTR-72, Fort Collins, CO: U.S. Department of Agriculture, Forest service, Rocky Mountain Research Station

Vrhovcak, M.B.; Zeljiko, T. \& Debrecin, N. (2005). External costs of electricity production: case study Croatia. Energy Policy, Vol. 33, No.11, pp. 1385-1395

Wagstaff, A. (1991). Health Care: QALYs and the equity-efficiency tradeoff. Journal of Health Economics. Vol. 10, pp. 21-41

Wang, H. \& Mullahy, J. (2006). Willingness to pay for reducing fatal risk by improving air quality: a contingent valuation study in Chongqing, China. Science of the Total Environment Vol. 367, No.1, pp. 50-57

Wang, Y. \& Zhang, Y-S. (2009). Air quality assessment by contingent valuation in Ji'nan, China. Journal of Environmental Management, Vol. 90, No. 2, pp. 1022-1029

Welsch, H. (2006). Environment and happiness: Valuation of air pollution using life satisfaction data. Ecological Economics, Vol. 58, No.4, pp. 801-813

Won Kim, C.; Phipps, T.T. \& Anselin, L. (2003). Measuring the Benefits of Air quality improvement: a spatial hedonic approach. Journal of Environmental Economics and Management, Vol. 45, No. 1, pp. 24-39

Yoo, S.H.; Kwak, S.J. \& Lee J.S. (2008). Using a choice experiment to measure the environmental costs of air pollution impacts in Seoul. Journal of Environmental Management, Vol.86, No. 1, pp. 308-318 


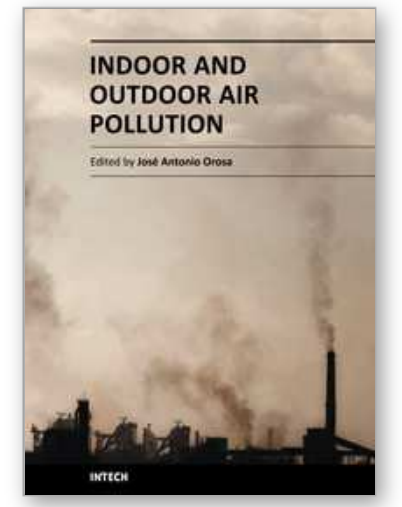

\author{
Indoor and Outdoor Air Pollution \\ Edited by Prof. JosÃ@ Orosa
}

ISBN 978-953-307-310-1

Hard cover, 126 pages

Publisher InTech

Published online 22, September, 2011

Published in print edition September, 2011

Air pollutants are continuously released from numerous sources into the atmosphere. Several studies have been carried out on the quantification of pollutants and their consequences on public health. Identification of the source characteristics of air pollution is an important step in the development of regional air quality control strategies. Air quality is a measure of the degree of ambient atmospheric pollution. Deterioration and damage to both public health and environment due to poor air quality have been recognized at a legislative and international level. In consequence, indoor and outdoor air quality must also be considered. This book tries to reveal different points of view of the wide concept of air quality in two different sections. In this context, there will be an initial introductory chapter on the main concepts of air quality, following which there will be real case studies on outdoor and indoor air quality with an aim to provide a guideline for future standards and research works.

\title{
How to reference
}

In order to correctly reference this scholarly work, feel free to copy and paste the following:

Eva Kougea and Phoebe Koundouri (2011). Air Quality Degradation: Can Economics Help in Measuring its Welfare Effects? A Review of Economic Valuation Studies, Indoor and Outdoor Air Pollution, Prof. JosÃ@) Orosa (Ed.), ISBN: 978-953-307-310-1, InTech, Available from: http://www.intechopen.com/books/indoor-andoutdoor-air-pollution/air-quality-degradation-can-economics-help-in-measuring-its-welfare-effects-a-review-ofeconomic-val

\section{INTECH}

open science | open minds

\author{
InTech Europe \\ University Campus STeP Ri \\ Slavka Krautzeka 83/A \\ 51000 Rijeka, Croatia \\ Phone: +385 (51) 770447 \\ Fax: +385 (51) 686166 \\ www.intechopen.com
}

\author{
InTech China \\ Unit 405, Office Block, Hotel Equatorial Shanghai \\ No.65, Yan An Road (West), Shanghai, 200040, China \\ 中国上海市延安西路65号上海国际贵都大饭店办公楼 405 单元 \\ Phone: +86-21-62489820 \\ Fax: $+86-21-62489821$
}


(C) 2011 The Author(s). Licensee IntechOpen. This chapter is distributed under the terms of the Creative Commons Attribution-NonCommercialShareAlike-3.0 License, which permits use, distribution and reproduction for non-commercial purposes, provided the original is properly cited and derivative works building on this content are distributed under the same license. 